\title{
DNA double strand breaks induced by low dose mammography X-rays in breast tissue: A pilot study
}

\author{
JULIE DEPUYDT ${ }^{1}$, TANGUY VIAENE ${ }^{1}$, PHILLIP BLONDEEL ${ }^{2}$, NATHALIE ROCHE ${ }^{2}$, \\ RUDY VAN DEN BROECKE ${ }^{3}$, HUBERT THIERENS ${ }^{1}$ and ANNE VRAL ${ }^{1}$ \\ ${ }^{1}$ Department of Basic Medical Sciences, University of Ghent; ${ }^{2}$ Plastic Surgery, Ghent University Hospital; \\ ${ }^{3}$ Department of Uro-Gynecology, University of Ghent, 9000 Ghent, Belgium
}

Received August 7, 2017; Accepted April 26, 2018

DOI: $10.3892 / \mathrm{ol} .2018 .9024$

\begin{abstract}
Breast tissue is very sensitive to ionizing radiation due to the presence of reproductive hormones, including estrogen. In the present pilot study, the efficiency of mammography X-rays to induce DNA double strand breaks (DSB) in mammary epithelial cells was investigated. For this, freshly resected healthy breast tissue was irradiated with $30 \mathrm{kV}$ mammography $\mathrm{X}$-rays in the dose range 0-500 mGy $(2,4,10,20,40,100$ and $500 \mathrm{mGy}$ ). Breast specimens were also irradiated with identical doses of ${ }^{60} \mathrm{Co} \gamma$-rays as a radiation quality standard. With the $\gamma \mathrm{H} 2 \mathrm{AX}$-foci assay, the number of DNA DSB induced by radiation were quantified in the mammary epithelial cells present in breast tissue. Results indicated that foci induced by $30 \mathrm{kV}$ $\mathrm{X}$-rays and $\gamma$-rays followed a biphasic linear dose-response. For $30 \mathrm{kV}$ X-rays, the slope in the low dose region (0-20 mGy) was 8.71 times steeper compared with the slope in the higher dose region (20-500 mGy). Furthermore, compared with $\gamma$-rays, $30 \mathrm{kV}$ X-rays were also more effective in inducing $\gamma \mathrm{H} 2 \mathrm{AX}$-foci. This resulted in a relative biological effectiveness (RBE) value of 1.82 in the low dose range. In the higher dose range, an $\mathrm{RBE}$ close to 1 was obtained. In conclusion, the results indicated the existence of a low dose hypersensitive response for DSB induction in the dose range representative for mammography screening, which is probably caused by the bystander effect. This could affect the radiation risk calculations for women participating in mammography screening.
\end{abstract}

\section{Introduction}

In many countries, screening programs based on periodic mammography are provided to women aged 45-50 to 70-75 years, to diagnose breast cancer in an early stage (1).

Correspondence to: Professor Anne Vral, Department of Basic Medical Sciences, University of Ghent, De Pintelaan 185 6B3, 9000 Ghent, Belgium

E-mail: anne.vral@ugent.be

Key words: double strand breaks, mammography, breast cancer, $\gamma \mathrm{H} 2 \mathrm{AX}$, radiation
Breast glandular doses are low and typically 3-5 mGy for a two-view mammography (2-4). However, the use of ionizing radiation always implies a risk for radiation-induced breast cancer.

Mammography radiation consists of low-energy X-rays with a typical peak and mean photon energy of $28-30 \mathrm{kV}$ and $15-20 \mathrm{keV}$ respectively. $30 \mathrm{kV}$ X-rays have a more-dense ionization pattern resulting in a higher linear energy transfer (LET) of $4.34 \mathrm{keV} / \mu \mathrm{m}$ compared to high energy photons such as e.g., ${ }^{60} \mathrm{Co} \gamma$-rays (LET $0.3 \mathrm{keV} / \mu \mathrm{m}$, energy $1.25 \mathrm{MeV}$ ). The biological impact of the higher LET of low-energy mammography X-rays compared to high energy photons is still a matter of debate. The International Commission on Radiological Protection (ICRP) acknowledges that, based on in vitro experiments on cells, there seems to be significant differences in relative biological effectiveness (RBE) of different low LET radiation qualities, but still recommends the use of an RBE of 1 for $30 \mathrm{kV} \mathrm{X}$-rays (5).

In the high dose range, starting from $100 \mathrm{mGy}$, there is a linear relationship with the dose received and the long term effects of radiation such as induction of cancer (6). The effects of low (<100 mGy) and very low doses (<10 mGy), typically applied in medical diagnostics, are debated, as the published data are more dispersed; on the contrary, for doses higher than $100 \mathrm{mGy}$ more consistent data are available (7-9). Furthermore, epidemiological data on the low dose range do not have sufficient statistical power to assess the long term radiation risks of the low and very low exposure levels (3). However, the inability to quantify these risks does not imply that the risk to the population is negligible. A very small risk, if applied to a large number of healthy individuals, can result in a significant public health problem (3).

In vitro studies investigating cellular and genetic effects can highlight the consequences of low and very low doses of ionizing radiation. After an exposure to just a few $\mathrm{mGy}$ damage to the DNA, such as DNA double strand breaks (DSB) evidenced by $\gamma \mathrm{H} 2 \mathrm{AX}$ foci, can be demonstrated (10-12) even in primary breast epithelial cells (13), and changes in transcription level of genes can also be detected (14-16). Doses as low as a few mGy have an impact on the cell physiology and gene expression analysis demonstrated that different gene profiles are activated after low and high doses of X-rays in whole blood (17). However, how these effects translate into low dose 
risks, and whether they have detrimental or beneficial effects, is still a matter of debate. In radiation protection practice a linear no threshold (LNT) extrapolation is used to calculate the risks at low doses using data from higher doses. However, this is just a working hypothesis which might underestimate or overestimate the effects of low dose radiation (3).

Most data on the low dose effects of mammography X-rays are derived from blood lymphocytes, primary fibroblasts or cell lines (18-20). However, the breast is a unique tissue in terms of sensitivity to radiation, due to the presence of reproductive hormones like estrogen. Estrogens can act as complete carcinogens as they stimulate both estrogen receptor-mediated cell proliferation and induce DNA damage through the formation of genotoxic metabolites such as reactive oxygen species (ROS) (21-24).

In this pilot study we investigated the effect of mammography X-rays in the dose range of 0-500 $\mathrm{mGy}$, with special emphasis on the very low doses (0-20 mGy), in mammary epithelial cells present in freshly resected healthy breast tissue. By using the $\gamma \mathrm{H} 2 \mathrm{AX}$-foci assay we quantified the number of DNA DSB induced by radiation in the glandular epithelial tissue (25). To study the RBE of mammography X-rays, ${ }^{60} \mathrm{Co} \gamma$-rays were used as reference radiation quality.

\section{Materials and methods}

Subjects, preparation of the breast tissue and irradiations. Non-cancerous, freshly resected breast tissue was collected during surgery in the department of plastic surgery and breast clinic of the Ghent University Hospital (Ghent, Belgium). Ethical clearance was received from the commission for medical ethics from the Ghent University hospital. Signed informed consent, allowing the analysis of the effects of irradiation on breast tissue, was obtained from each donor.

From a total of 18 specimens, 15 breast tissue-samples were of good quality (see further): 11 out of 15 were from women without an increased risk for breast cancer (mammectomy for esthetical reasons), whereas 4 were from women with a high risk profile for breast cancer of which 3 had a confirmed BRCA mutation (we do not have the information if it was a BRCA1 or 2 mutation). Mean age of the women was 41 years. None of the women had breast cancer.

Immediately after resection, the tissue samples were processed for irradiation by first removing the fat tissue. The remaining connective tissue containing the mammary epithelial cells was cut into slices with a thickness between 1.5 and $2 \mathrm{~mm}$, while being kept in Ringer's solution $(9 \mathrm{~g} / 1$ $\mathrm{NaCl}$ (Sigma-Aldrich, Bornem, Belgium), $0.42 \mathrm{~g} / 1 \mathrm{CaCl}_{2}$ and $0.24 \mathrm{~g} / 1 \mathrm{KCl}$ (VWR, Leuven, Belgium), $\mathrm{pH}$ 7.2). The slices of breast tissue were kept until irradiation in a $5 \% \mathrm{CO}_{2}$-incubator. Once the slices of breast tissue were ready for irradiation, they were kept in a $5 \% \mathrm{CO}_{2}$-incubator at $37^{\circ} \mathrm{C}$ in DMEM/F12-ham medium (Invitrogen, Merelbeke, Belgium) supplemented with $5 \%$ fetal calf serum (Invitrogen), antibiotics and growth factors [10 $\mu \mathrm{g} / \mathrm{ml}$ insulin (Sigma, Belgium); $0.5 \mu \mathrm{g} / \mathrm{ml}$ hydrocortisone (Sigma); $20 \mathrm{ng} / \mathrm{ml}$ epidermal growth factor (Tebu-bio, Boechout, Belgium); $50 \mathrm{U} / \mathrm{ml}$ penicillin and $50 \mu \mathrm{g} / \mathrm{ml}$ streptomycin (Invitrogen)].

Samples from each donor were irradiated with mammography X-rays, with doses ranging from 2 to $500 \mathrm{mGy}$ (doses:
2, 4, 10, 20, 40, 100 and $500 \mathrm{mGy}$ ). Samples from the same donors were also irradiated with identical doses of ${ }^{60} \mathrm{Co} \gamma$-rays, used as reference radiation. Mammography-irradiations were performed with a Siemens Mammomat3 producing a $30 \mathrm{kV}$ $\mathrm{Mo} / \mathrm{Mo} \mathrm{X}$-ray spectrum at a dose rate of $0.125 \mathrm{~Gy} / \mathrm{min}$. As this mammography $\mathrm{X}$-ray device is designed to deliver very low doses, the number of doses in the higher dose range (20-500 mGy) had to be kept to a minimum. A layer of exactly $2 \mathrm{~mm}$ medium, containing the slices of breast tissue, was irradiated at $37^{\circ} \mathrm{C}$. The irradiations with ${ }^{60} \mathrm{Co} \gamma$-rays were performed in a water bath at $37^{\circ} \mathrm{C}$ at a dose rate of $5 \mathrm{mGy} / \mathrm{min}$ for doses up to $40 \mathrm{mGy}$ and at a dose rate of $0.6 \mathrm{~Gy} / \mathrm{min}$ for higher doses. Within each experiment sham-irradiated controls were included.

Fixation, embedding and haematoxylin-eosin staining. Immediately after irradiation, the tissue samples were incubated at $37^{\circ} \mathrm{C}$ for $30 \mathrm{~min}$, the time for maximal $\gamma \mathrm{H} 2 \mathrm{AX}$ foci-formation (26). Thereafter, samples were transferred to cold ringer's solution and kept on ice-water to inhibit repair processes. Subsequently they were transferred to paraformaldehyde (PFA; 4\%; VWR) for fixation.

After $24 \mathrm{~h}$ in PFA the tissue-samples were dehydrated and embedded in paraffin. Tissue sections of $5 \mu \mathrm{m}$ were cut with a microtome. Two tissue sections for each specimen were placed on the same slide and multiple slides were made.

The quality of the tissue and the presence of mammary glands was inspected by performing a haematoxylin-eosin staining using a multipurpose slide staining device (Robot stainer: Microm HMS 740; Microm, Walldorf, Germany).

$\gamma H 2 A X$ immunostaining. Prior to the $\gamma \mathrm{H} 2 \mathrm{AX}$ immunostaining, tissue sections were deparaffinised and rehydrated using the Robot stainer (Microm HMS 740; Microm).

Antigen retrieval was performed in sodium citrate buffer (0.2 g/l citric acid, pH 6; Merck KGaA, Darmstadt, Germany). The tissue sections were brought in the buffer and boiled twice during 5 min using a microwave. After washing of the sections in PBS, they were pretreated in $3 \% \mathrm{H}_{2} \mathrm{O}_{2}$ (VWR) to inactivate the endogenous peroxidases. Sections were further incubated in blocking serum (BS) (PBS $5 \mathrm{ml}$, BSA $50 \mathrm{mg}$ (bovine serum albumin; Roche Diagnostics, Vilvoorde, Belgium); NRS $0.250 \mathrm{ml}$ [Normal rabbit serum; Dako; Agilent Technologies, Inc., Santa Clara, CA, USA); Tween-20 (1 ml 10\% Tween-20 (VWR)] for $30 \mathrm{~min}$ to avoid nonspecific binding and to permeabilize the membranes.

Immunostaining was done using a tri-step reaction using consecutively a mouse-anti- $\gamma \mathrm{H} 2 \mathrm{AX}$ primary antibody [Biolegend, Trembodegem, Belgium; 2 h, 1/1,000 in PBS with $10 \% \mathrm{BS}$ at room temperature (RT)], a biotinylated rabbit-anti-mouse secondary antibody (Dako; Agilent Technologies, Inc.; $30 \mathrm{~min}, 1 / 200$ in PBS with $10 \%$ BS at RT) and streptavidine-horse radish peroxidase (Dako; Agilent Technologies, Inc.; $30 \mathrm{~min}, 1 / 200$ in PBS at RT). Between the steps the tissue-sections were washed in PBS $(2 \times 5 \mathrm{~min})$. Next, the sections were incubated with $\mathrm{DAB}-\mathrm{NiCl}_{2}$ (stock solution (ss) DAB: $25 \mathrm{mg} / 1 \mathrm{ml} \mathrm{AD;} \mathrm{ss} \mathrm{NiCl}_{2}: 4 \mathrm{~g} / 50 \mathrm{ml} \mathrm{AD}$; work solution: $200 \mu \mathrm{l} \mathrm{DAB}$ ss; $50 \mu \mathrm{NiCl}_{2}$ ss; $10 \mathrm{ml} \mathrm{PBS}$; $5 \mu \mathrm{H}_{2} \mathrm{O}_{2}$ ) during $10 \mathrm{~min}$ in the dark to visualize the $\gamma \mathrm{H} 2 \mathrm{AX}$ foci. Slides were washed during $10 \mathrm{~min}$ in running tap water 
before dehydrating and mounting the sections with mounting medium (Thermo Fisher Scientific, Inc., Waltham, MA, USA). Slides were sealed with a cover slip.

Foci scoring. $\gamma \mathrm{H} 2 \mathrm{AX}$-foci scoring was done manually, using a light microscope (Leica LEITZ-DMRB; Leica, Diegem, Belgium) at 63X magnification (Fluotar 63X/1.25 Oil; Leica). Per breast tissue sample and per radiation condition, at least two tissue-sections were scored by two experienced researchers. In each section the number of $\gamma \mathrm{H} 2 \mathrm{AX}$ foci in 100 nuclei was scored, if possible in at least 4 different glandular groups. Only the epithelial cells from the inner luminar layer of the glands were taken into account.

Analysis. For the analysis of the $\gamma \mathrm{H} 2 \mathrm{AX}$ foci data, two linear fittings $(Y=c+\alpha D)$ were performed for both radiation qualities (30 $\mathrm{kV} \mathrm{X-rays} \mathrm{and} \gamma$-rays): one in the very low dose range of $0-20 \mathrm{mGy}$ and one in the higher range of 20-500 mGy.

To compare the effects of the different radiation qualities, the RBE of $30 \mathrm{kV}$ X-rays compared to $\gamma$-rays was calculated using the following formula: ' $\mathrm{RBE}=\alpha_{x} / \alpha_{\gamma}$ '. The RBE is defined as a ratio, between two absorbed doses delivered with two radiation qualities, one of which is a 'reference radiation', that result in the same effect in a given biological system, under identical conditions.

Statistical analysis was done using the program SigmaPlot (SigmaPlot for Windows Version 13.0; Systat. Software, Inc., San Jose, CA, USA). To compare two groups of data, a Student t-test or a rank sum test was used, depending on the normal distribution of the data.

\section{Results}

Hematoxylin and eosin $(H \& E)$ staining. Inspection of the tissue samples by H\&E staining revealed that for some donors, the samples contained cells with an abnormal morphology. In those cases, all tissue samples of that donor were excluded from the study.

Furthermore, in a number of tissue samples no glands were present. Especially samples taken from elderly women tended to contain a very limited amount of glandular epithelial tissue. Tissue samples containing less than 100 epithelial cells were discarded. As a result, per donor not all dose points and sham-irradiated controls could be analyzed for foci formation.

$\gamma H 2 A X$ foci assay. Examples of the foci staining are given in Fig. 1. The use of DAB- $\mathrm{NiCl}_{2}$ resulted in very distinct black foci and a light background staining of the tissue. No counterstain was used, since the immunostaining already resulted in sufficient contrast to the tissue and counterstaining tended to darken the nuclei, reducing the ability to distinguish the foci.

The number of background foci could be measured in all 4 high-risk women and in 5 women with a normal risk profile. No difference in the mean number of background foci could be detected between women at high risk for breast cancer $(0.44$ foci/cell \pm 0.15$)$ and women without an elevated risk $(0.36$ foci/cell \pm 0.10$)(\mathrm{P}=0.68)$. Also for all irradiated samples (2-500 mGy), no significant differences between women with and without elevated risk could be observed.
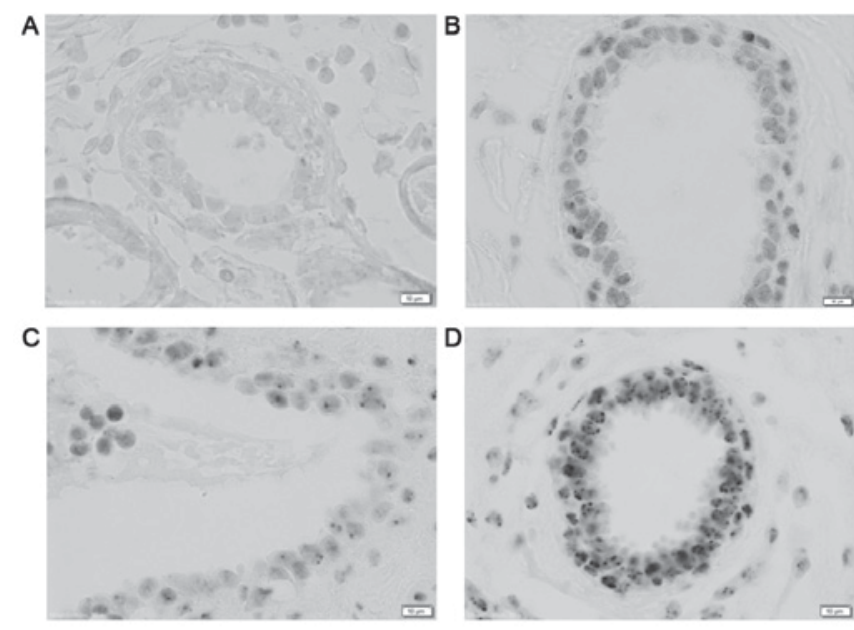

Figure 1. $\gamma \mathrm{H} 2 \mathrm{AX}$ foci staining of breast tissue sections showing glandular ducts surrounded by connective tissue. $\gamma \mathrm{H} 2 \mathrm{AX}$ foci, visible as black dots, were scored in the epithelial cells lining the glandular ducts. Images were taken with a $63 \mathrm{X}$ objective. (A) Negative control (no primary antibody); (B) unirradiated sample; (C) sample irradiated with $100 \mathrm{mGy}$; (D) sample irradiated with $500 \mathrm{mGy}$. Scale bar $10 \mu \mathrm{m}$.

As no differences were observed between women with and without elevated genetic breast cancer risk, all the data were pooled (Table I). The mean number of background foci in the pooled samples was 0.38 foci/cell \pm 0.08 . The threshold detection dose, leading to a significant increase in number of foci per cell, was $10 \mathrm{mGy}$ after irradiation with $30 \mathrm{kV}$ X-rays $(\mathrm{P}=0.0487)$ while this was $20 \mathrm{mGy}$ after irradiation with ${ }^{60} \mathrm{Co} \gamma$-rays $(\mathrm{P}=0.0358)$.

The dose response relationship over the whole dose range shows a biphasic linear behavior for both $30 \mathrm{kV}$ X-rays and $\gamma$-rays, with the very low dose range ( $0-20 \mathrm{mGy})$ being characterized by a steeper slope than the higher dose range (20-500 mGy) (Fig. 2). An overview of the $\alpha$-values or slopes of the linear fittings performed in both dose ranges are given in Table II. It can be observed that the slope in the very low dose range is 8.71, resp. 5.77 times steeper than the slope in the higher dose range for $30 \mathrm{kV} \mathrm{X-rays,} \mathrm{resp.} \gamma$-rays. Table I also lists the RBE $\left(=\alpha_{30 \mathrm{kV}} / \alpha_{\gamma}\right)$ values. In the dose range $0-20 \mathrm{mGy}, 30 \mathrm{kV}$ X-rays are more effective in inducing DNA DSB than $\gamma$-rays $(\mathrm{RBE}=1.82)$. In the higher dose range an RBE close to 1 was obtained.

\section{Discussion}

A mammography examination consists of 2 views of approximately $2 \mathrm{mGy}$ each resulting in a glandular dose of 3-5 mGy. In most screening programs 10 examinations are performed during a screening period of about 20 years. Although the dose per examination is very small, the risk for radiation-induced breast cancer cannot be neglected in view of the large population size and the repetitive character involved in this type of asymptomatic screening. At low doses, phenomena such as hypersensitivity, bystander effect, adaptive response, threshold hypothesis and hormetic response can play a role $(3,6,27)$ and extrapolation of radiation-effects from the high-dose range to the low-dose range by the LNT model can lead to both an underestimation and overestimation of the low-dose effects of radiation. 
Table I. Yield of $\gamma \mathrm{H} 2 \mathrm{AX}$ foci in cells exposed to increasing doses of $30 \mathrm{kV}$ X-rays and $\gamma$-rays.

\begin{tabular}{|c|c|c|c|c|c|c|}
\hline \multirow[b]{2}{*}{$\begin{array}{l}\text { Dose } \\
\text { (mGy) }\end{array}$} & \multicolumn{3}{|c|}{$30 \mathrm{kV}$ X-rays } & \multicolumn{3}{|c|}{$\gamma$-rays } \\
\hline & $\begin{array}{c}\text { Number of scored } \\
\text { samples }\end{array}$ & $\begin{array}{l}\text { Mean number of } \\
\text { foci per cell }\end{array}$ & SEM & $\begin{array}{c}\text { Number of scored } \\
\text { samples }\end{array}$ & $\begin{array}{l}\text { Mean number of } \\
\text { foci per cell }\end{array}$ & SEM \\
\hline 0 & 9 & 0.38 & 0.08 & 9 & 0.38 & 0.08 \\
\hline 2 & 4 & 0.55 & 0.14 & 6 & 0.33 & 0.10 \\
\hline 4 & 6 & 0.50 & 0.11 & 10 & 0.45 & 0.09 \\
\hline 10 & 4 & 0.60 & 0.08 & 5 & 0.41 & 0.07 \\
\hline 20 & 2 & 0.94 & 0.34 & 4 & 0.73 & 0.07 \\
\hline 40 & 8 & 0.65 & 0.07 & 8 & 0.59 & 0.06 \\
\hline 100 & 5 & 1.06 & 0.19 & 5 & 1.06 & 0.11 \\
\hline 500 & 4 & 2.29 & 0.82 & 4 & 1.96 & 0.62 \\
\hline
\end{tabular}

The mean number of $\gamma \mathrm{H} 2 \mathrm{AX}$ foci per cell was obtained by averaging the data of samples taken from different donors (number of scored samples). For each donor specimen, two tissue sections were analyzed and in each section $\gamma \mathrm{H} 2 \mathrm{AX}$ foci were scored in 100 glandular epithelial cells. SEM, standard error of the mean.

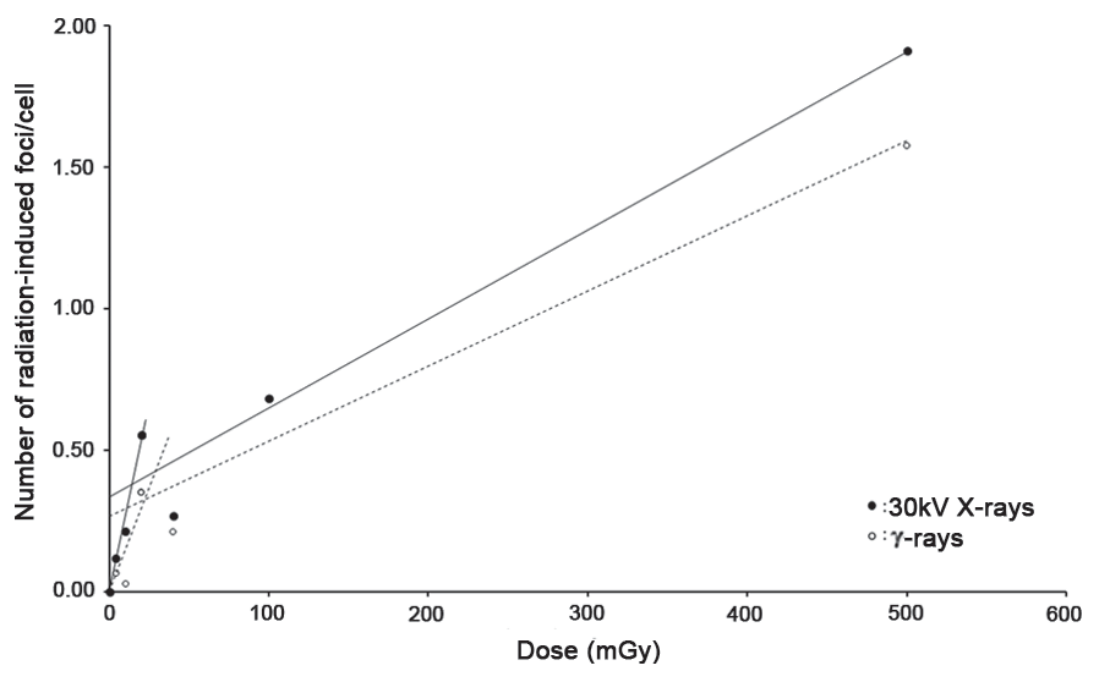

Figure 2. Biphasic dose response for $\gamma \mathrm{H} 2 \mathrm{AX}$ foci induction after irradiation with $30 \mathrm{kV} \mathrm{X}$-rays and ${ }^{60} \mathrm{Co} \gamma$-rays. The linear regression curves in the very low dose range (0-20 mGy) and the higher dose range (20-500 mGy) are shown (full lines: $30 \mathrm{kV} \mathrm{X-rays,} \mathrm{dashed} \mathrm{lines:}{ }^{60} \mathrm{Co} \gamma$-rays). Each data point represents the mean number of $\gamma \mathrm{H} 2 \mathrm{AX}$ foci per cell, obtained by averaging the data of samples taken from different donors. For each donor specimen, two tissue sections were analyzed and in each section $\gamma \mathrm{H} 2 \mathrm{AX}$ foci were scored in 100 glandular epithelial cells The mean foci numbers together with the standard errors are given in Table I. Note that for $100 \mathrm{mGy}$ an identical mean foci number was obtained with both radiation qualities.

In this study we wanted to investigate the biological efficacy of mammography X-rays for DNA DSB induction in glandular epithelial cells present in resected breast tissue of healthy women and ex vivo irradiated with very low doses. For this, our study is unique as the set-up corresponds as close as possible to the exact physiological conditions of mammography screening.

To focus on a high number of data points in the high dose range was beyond the scope of this study, as we and others have previously published such data $(19,28-30)$. Nevertheless, the lack of details between 100 and 500 mGy may be a possible limitation of our study.

As our population included 4 women with an increased genetic risk for breast cancer, we first investigated if a significant difference could be observed between those women and women without a high risk for breast cancer in the number of background $\gamma \mathrm{H} 2 \mathrm{AX}$ foci, and in the number of radiation-induced foci at any dose. No significant differences were detected. These results are in contrast with the results of Colin et al who found an increased background number of $\gamma \mathrm{H} 2 \mathrm{AX}$ and an increased radiation-induced number of foci (2, 4 mGy and fractionated $2+2 \mathrm{mGy}$ ) in cell cultures of primary mammary epithelial cells of high-risk patients compared to low-risk patients (13). Since $\gamma \mathrm{H} 2 \mathrm{AX}$ functions upstream of BRCA1 and BRCA2, it is not surprising that no differences are found in $\gamma \mathrm{H} 2 \mathrm{AX}$ induction between donors with and without a BRCA mutation 30 min after irradiation (31). Analysis of residual DSB by scoring $\gamma \mathrm{H} 2 \mathrm{AX}$ foci at later time points after irradiation (e.g., $24 \mathrm{~h}$ ) is better suited to detect deficiencies in DSB-repair, that may be related to 
Table II. Overview of the slopes or $\alpha$-values of the linear dose response fittings $(Y=c+\alpha D)$ performed in the 0-20 and 20-500 mGy dose-range.

\begin{tabular}{|c|c|c|c|c|c|c|}
\hline & 0-20 mGy & $95 \% \mathrm{CI}$ & $20-500$ mGy & $95 \% \mathrm{CI}$ & $\alpha_{\mathrm{L}} / \alpha_{\mathrm{H}}$ & $95 \% \mathrm{CI}$ \\
\hline$\alpha_{30 \mathrm{kV} \text { X-rays }}$ & 0.027 & $0.023-0.031$ & 0.0031 & $0.0012-0.0050$ & 8.71 & $4.64-25.20$ \\
\hline$\alpha_{\gamma \text {-rays }}$ & 0.015 & $0.004-0.020$ & 0.0026 & $0.0009-0.0044$ & 5.77 & $0.94-22.14$ \\
\hline RBE & 1.82 & $1.17-7.56$ & 1.19 & $0.28-5.58$ & & \\
\hline
\end{tabular}

Table indicated the $30 \mathrm{kV}$ X-rays and $\gamma$-rays with the RBE values $\left(\alpha_{30 \mathrm{kV}} \alpha_{\mathrm{y}}\right)$ and the ratio of the $\alpha$-values in the lower $(\mathrm{L})$ and higher $(\mathrm{H})$ dose range $\left(\alpha_{L} / \alpha_{H}\right)$. RBE, relative biological effectiveness; 95\% CI, 95\% confidence interval.

cancer induction, but this was not the aim of our study. In the paper of van Oorschot et al (32), radiation-induced foci were analyzed in repair deficient cell lines immediately and $24 \mathrm{~h}$ after irradiation. Differences in foci number were only observed when the cells were allowed to repair the DNA DSB for $24 \mathrm{~h}$ after irradiation. At $30 \mathrm{~min}$ post irradiation no differences were observed, in agreement with our findings.

As no differences were observed the data of all donors were pooled for further analysis. The threshold detection dose obtained with the $\gamma \mathrm{H} 2 \mathrm{AX}$ foci-assay after irradiation with $30 \mathrm{kV} \mathrm{X}$-rays was $10 \mathrm{mGy}$. In a previous study using lymphocytes, we also found a significant increase in $\gamma \mathrm{H} 2 \mathrm{AX}$ foci after $10 \mathrm{mGy}$ of $30 \mathrm{kV} \mathrm{X}$-rays (19). Other research groups showed a statistical significant increase of DNA DSB in MCF-10A cells after $9 \mathrm{mGy}$ of $30 \mathrm{kV}$ X-rays (20) and in cultured primary mammary epithelial cells a threshold detection dose of $4 \mathrm{mGy}$ and of a fractionated $2+2 \mathrm{mGy}$ was reported (13). These results suggest that the threshold detection dose of mammography $\mathrm{X}$-rays for DSB induction is around or below $10 \mathrm{mGy}$.

Although some literature data report a linear dose response for $\gamma \mathrm{H} 2 \mathrm{AX}$, pointing to a proportionally identical biological response to low and high radiation doses, other studies demonstrated that for very low doses, foci induction is much higher than at higher doses pointing to the phenomenon of low dose hypersensitivity (for a review see Beels et al $(33,34)$ ). Beels et al (33) found a hypersensitive response in whole blood in pediatric patients exposed in vivo to low doses of X-rays for cardiac catheterization (mean dose $6 \mathrm{mSv}$ ). They further confirmed these results with a study on $\gamma \mathrm{H} 2 \mathrm{AX}$-induction in whole blood and isolated T-lymphocytes irradiated in vitro with $100 \mathrm{kVp} \mathrm{X}$-rays and $\gamma$-rays (34). When whole blood was irradiated with $\mathrm{X}$-rays, a biphasic dose response was observed, characterized by a very steep response in the $0-10 \mathrm{mGy}$ dose range, which became less steep if doses higher than $20 \mathrm{mGy}$ were used. After irradiation with $\gamma$-rays, the biphasic effect was still there, but much less pronounced. The effects were also less pronounced when isolated lymphocytes instead of whole blood was used. They concluded that both cellular environment and radiation quality play a role in this hypersensitive response. A strong correlation between cell culture conditions and a low dose hypersensitive response was also found by Groesser et al (35).

The results obtained in this study are comparable with those of Beels et al $(33,34)$. A clear biphasic dose response was noted, with a hypersensitive component for both $30 \mathrm{kV}$ $\mathrm{X}$-rays and $\gamma$-rays in the very low dose range of $0-20 \mathrm{mGy}$, indicating that the LNT-model results in an underestimation of the induced DNA damage. In the very low dose range, $30 \mathrm{kV}$ $\mathrm{X}$-rays were also more effective in inducing DNA DSB than $\gamma$-rays resulting in an RBE of 1.82. In the higher dose range of 20-500 mGy an RBE close to 1 was obtained.

The low dose hypersensitivity observed in our study is probably caused by the bystander effect. The bystander effect is largely propagated by damaged cells which release signaling molecules to neighboring cells via gap-junction mediated intercellular communication and via the release of diffusible factors such as ROS into the extra-cellular environment (36-40). In our study, $2 \mathrm{~mm}$ thick slices of breast tissue, including epithelial glandular structures, were irradiated and as such, gap-junction mediated communication between cells in their natural micro-environment is still intact. Also, estrogens, which are highly available in breast tissue, are an important source of ROS.

Mills et al on the other hand, did not find an increased RBE in the low dose range (0-30 $\mathrm{mGy}$ ) for mammography X-rays, on the contrary, they found an RBE value of only 1.1 (20). The difference between our study - performed on freshly resected breast tissue containing mammary glands - and the study of Mills et al could be due to the fact that Mills et al worked with an MCF10A cell line and not with breast tissue sections. In their study, MCF-10A cells were grown in monolayers, which could influence gap-junction mediated intercellular communication. Furthermore, the cells were kept at $0^{\circ} \mathrm{C}$ some time before, during and after the irradiation. From literature it is known that hypothermia is a known radioprotectans and has a protective role against the damaging effects of $\operatorname{ROS}(41,42)$. Moreover, hypothermia could influence cell processes such as cellular communication.

Overall, it seems that the bystander effect might induce a hypersensitive response in breast tissue and that this response is also dependent on the energy deposition which differs between $30 \mathrm{kV} \mathrm{X-rays} \mathrm{and} \gamma$-rays, tissue culture conditions and temperature.

In conclusion, our results indicate the existence of a low dose (0-20 mGy) hypersensitive response in glandular epithelial cells of breast tissue, with an $\mathrm{RBE}=1.82$ for mammography X-rays. The impact of these findings on the radiation risk calculations for women participating in mammography screenings is unclear, since several parameters will affect the repair of these radiation-induced DSB. However, in our previous study, we have shown that DSB induced by mammography X-rays are more difficult to repair 
than those induced by $\gamma$-rays, and that the same number of mammography induced DSB resulted in a higher number of chromosomal aberrations which are a hallmark for cancer (19).

These results are based on a limited patient-population and a future larger study, including ROS measurements, will be needed to confirm the obtained results.

\section{Acknowledgements}

The authors would like to thank Mrs. Leen Pieters from the Department of Basic Medical Sciences, University of Ghent (Ghent, Belgium) for her technical assistance.

\section{Funding}

No funding was received.

\section{Availability of data and materials}

The datasets used and/or analyzed during the current study are available from the corresponding author on reasonable request.

\section{Authors' contributions}

JD performed the experimental research and contributed to the analysis and interpretation of the data and manuscript preparation; TV performed experimental research; PB, NR and RVDB were responsible for the clinical part and provided patient material; HT was responsible for the conception and design of the radiation procedures and contributed to the interpretation of the radiation experiments; AV was responsible for the conception and design of the study, the interpretation of the data, the critical revision of the manuscript draft and the final approval of the submitted version.

\section{Ethics approval and consent to participate}

All samples were taken from patients that signed an informed consent stating that their material could be used for anonymous analysis and publication of data. The handling of patient material and data was approved and performed according to the guidelines of the Ghent University Hospital's Ethical Committee and the Helsinki Declaration on medical ethics and later amendments.

\section{Patient consent for publication}

Not applicable.

\section{Competing interests}

The authors declare that they have no competing interests.

\section{References}

1. Altobelli E and Lattanzi A: Breast cancer in European Union: An update of screening programmes as of March 2014 (review). Int J Oncol 45: 1785-1792, 2014.
2. Klein R, Aichinger H, Dierker J, Jansen JT, Joite-Barfuss S, Säbel M, Schulz-Wendtland R and Zoetelief J: Determination of average glandular dose with modern mammography units for two large groups of patients. Phys Med Biol 42: 651-671, 1997.

3. Brenner DJ, Doll R, Goodhead DT, Hall EJ, Land CE, Little JB, Lubin JH, Preston DL, Preston RJ, Puskin JS, et al: Cancer risks attributable to low doses of ionizing radiation: Assessing what we really know. Proc Natl Acad Sci USA 100: 13761-13766, 2003.

4. Hendrick RE, Pisano ED, Averbukh A, Moran C, Berns EA, Yaffe MJ, Herman B, Acharyya S and Gatsonis C: Comparison of acquisition parameters and breast dose in digital mammography and screen-film mammography in the American College of Radiology Imaging Network digital mammographic imaging screening trial. AJR Am J Roentgenol 194: 362-369, 2010.

5. The 2007 recommendations of the International Commission on Radiological Protection: ICRP publication 103. Ann ICRP 37: 1-332, 2007.

6. Averbeck D: Does scientific evidence support a change from the LNT model for low-dose radiation risk extrapolation? Health Phys 97: 493-504, 2009.

7. Heyes GJ, Mill AJ and Charles MW: Mammography-oncogenecity at low doses. J Radiol Prot 29: A123-A132, 2009.

8. Hunter N and Muirhead CR: Review of relative biological effectiveness dependence on linear energy transfer for low-LET radiations. J Radiol Prot 29: 5-21, 2009.

9. Leenhouts HP and Chadwick KH: Dose-effect relationships, epidemiological analysis and the derivation of low dose risk. J Radiol Prot 31: 95-105, 2011.

10. Rothkamm K and Löbrich M: Evidence for a lack of DNA double-strand break repair in human cells exposed to very low x-ray doses. Proc Natl Acad Sci USA 100: 5057-5062, 2003.

11. Bakkenist CJ and Kastan MB: Initiating cellular stress responses. Cell 118: 9-17, 2004.

12. Grudzenski S, Raths A, Conrad S, Rübe CE and Löbrich M: Inducible response required for repair of low-dose radiation damage in human fibroblasts. Proc Natl Acad Sci USA 107: 14205-14210, 2010.

13. Colin C, Devic C, Noël A, Rabilloud M, Zabot MT, Pinet-Isaac S, Giraud S, Riche B, Valette PJ, Rodriguez-Lafrasse C and Foray N: DNA double-strand breaks induced by mammographic screening procedures in human mammary epithelial cells. Int $\mathrm{J}$ Radiat Biol 87: 1103-1112, 2011.

14. Amundson SA, Lee RA, Koch-Paiz CA, Bittner ML, Meltzer P, Trent JM and Fornace AJ Jr: Differential responses of stress genes to low dose-rate gamma irradiation. Mol Cancer Res 1: 445-452, 2003.

15. Franco N, Lamartine J, Frouin V, Le Minter P, Petat C, Leplat JJ, Libert F, Gidrol X and Martin MT: Low-dose exposure to gamma rays induces specific gene regulations in normal human keratinocytes. Radiat Res 163: 623-635, 2005.

16. Yang F, Stenoien DL, Strittmatter EF, Wang J, Ding L, Lipton MS, Monroe ME, Nicora CD, Gristenko MA, Tang K, et al: Phosphoproteome profiling of human skin fibroblast cells in response to low- and high-dose irradiation. J Proteome Res 5: 1252-1260, 2006.

17. El-Saghire H, Thierens H, Monsieurs P, Michaux A, Vandevoorde $C$ and Baatout S: Gene set enrichment analysis highlights different gene expression profiles in whole blood samples X-irradiated with low and high doses. Int J Radiat Biol 89: 628-638, 2013.

18. Kühne M, Urban G, Frankenberg D and Löbrich M: DNA double-strand break misrejoining after exposure of primary human fibroblasts to CK characteristic X rays, $29 \mathrm{kVp} X$ rays and 60Co gamma rays. Radiat Res 164: 669-676, 2005.

19. Depuydt J, Baert A, Vandersickel V, Thierens H and Vral A: Relative biological effectiveness of mammography X-rays at the level of DNA and chromosomes in lymphocytes. Int J Radiat Biol 89: 532-538, 2013.

20. Mills CE, Thome C, Koff D, Andrews DW and Boreham DR: The relative biological effectiveness of low-dose mammography quality $\mathrm{X}$ rays in the human breast MCF-10A cell line. Radiat Res 183: 42-51, 2015.

21. Fucic A and Gamulin M: Interaction between ionizing radiation and estrogen: What we are missing? Med Hypotheses 77: 966-969, 2011.

22. Shao C, Folkard M, Held KD and Prise KM: Estrogen enhanced cell-cell signalling in breast cancer cells exposed to targeted irradiation. BMC Cancer 8: 184, 2008. 
23. Liehr JG: Genotoxicity of the steroidal oestrogens oestrone and oestradiol: Possible mechanism of uterine and mammary cancer development. Hum Reprod Update 7: 273-281, 2001.

24. Cavalieri E, Chakravarti D, Guttenplan J, Hart E, Ingle J, Jankowiak R, Muti P, Rogan E, Russo J, Santen R and Sutter T: Catechol estrogen quinones as initiators of breast and other human cancers: Implications for biomarkers of susceptibility and cancer prevention. Biochim Biophys Acta 1766: 63-78, 2006.

25. Rogakou EP, Pilch DR, Orr AH, Ivanova VS and Bonner WM: DNA double-stranded breaks induce histone $\mathrm{H} 2 \mathrm{AX}$ phosphorylation on serine 139. J Biol Chem 273: 5858-5868, 1998.

26. Rothkamm K and Horn S: gamma-H2AX as protein biomarker for radiation exposure. Ann Ist Super Sanita 45: 265-271, 2009

27. Averbeck D: Non-targeted effects as a paradigm breaking evidence. Mutat Res 687: 7-12, 2010.

28. Beyreuther E, Dörr W, Lehnert A, Lessmann E and Pawelke J: Relative biological effectiveness of 25 and $10 \mathrm{kV} \mathrm{X-rays} \mathrm{for} \mathrm{the}$ induction of chromosomal aberrations in two human mammary epithelial cell lines. Radiat Environ Biophys 48: 333-340, 2009.

29. Beyreuther E, Lessmann E, Pawelke J and Pieck S: DNA double-strand break signalling: X-ray energy dependence of residual co-localised foci of gamma-H2AX and 53BP1. Int $\mathrm{J}$ Radiat Biol 85: 1042-1050, 2009.

30. Lehnert A, Lessmann E, Pawelke J and Dörr W: RBE of $25 \mathrm{kV}$ $\mathrm{X}$-rays for the survival and induction of micronuclei in the human mammary epithelial cell line MCF-12A. Radiat Environ Biophys 45: 253-260, 2006.

31. Roy R, Chun J and Powell SN: BRCA1 and BRCA2: Different roles in a common pathway of genome protection. Nat Rev Cancer 12: 68-78, 2011.

32. van Oorschot B, Hovingh S, Dekker A, Stalpers LJ and Franken NA: Predicting radiosensitivity with gamma-H2AX foci assay after single high-dose-rate and pulsed dose-rate ionizing irradiation. Radiat Res 185: 190-198, 2016.

33. Beels L, Bacher K, De Wolf D, Werbrouck J and Thierens H: gamma-H2AX foci as a biomarker for patient X-ray exposure in pediatric cardiac catheterization: Are we underestimating radiation risks? Circulation 120: 1903-1909, 2009.
34. Beels L, Werbrouck J and Thierens H: Dose response and repair kinetics of gamma-H2AX foci induced by in vitro irradiation of whole blood and T-lymphocytes with X- and gamma-radiation. Int J Radiat Biol 86: 760-768, 2010.

35. Groesser T, Cooper B and Rydberg B: Lack of bystander effects from high-LET radiation for early cytogenetic end points. Radiat Res 170: 794-802, 2008.

36. Azzam EI, de Toledo SM and Little JB: Direct evidence for the participation of gap junction-mediated intercellular communication in the transmission of damage signals from alpha-particle irradiated to nonirradiated cells. Proc Natl Acad Sci USA 98: 473-478, 2001

37. Azzam EI, de Toledo SM and Little JB: Stress signaling from irradiated to non-irradiated cells. Curr Cancer Drug Targets 4: 53-64, 2004.

38. Hanot M, Hoarau J, Carrière M, Angulo JF and Khodja H: Membrane-dependent bystander effect contributes to amplification of the response to alpha-particle irradiation in targeted and nontargeted cells. Int J Radiat Oncol Biol Phys 75: 1247-1253, 2009.

39. Mothersill C and Seymour C: Radiation-induced bystander effects: Past history and future directions. Radiat Res 155: 759-767, 2001.

40. Zhou H, Suzuki M, Geard CR and Hei TK: Effects of irradiated medium with or without cells on bystander cell responses. Mutat Res 499: 135-141, 2002.

41. Lisowska H, Wegierek-Ciuk A, Banasik-Nowak A, Braziewicz J, Wojewodzka M, Wojcik A and Lankoff A: The dose-response relationship for dicentric chromosomes and $\gamma$-H2AX foci in human peripheral blood lymphocytes: Influence of temperature during exposure and intra- and inter-individual variability of donors. Int J Radiat Biol 89: 191-199, 2013.

42. Dang L, Lisowska H, Manesh SS, Sollazzo A, Deperas-Kaminska M, Staaf E, Haghdoost S, Brehwens K and Wojcik A: Radioprotective effect of hypothermia on cells-a multiparametric approach to delineate the mechanisms. Int J Radiat Biol 88: 507-514, 2012. 